\begin{tabular}{|c|c|c|}
\hline \multirow{2}{*}{ FVCDI I ENT } & $\begin{array}{l}\text { International Journal of Current Research in } \\
\text { Biosciences and Plant Biology }\end{array}$ & 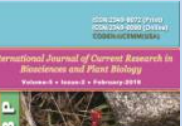 \\
\hline & Volume $5 \bullet$ Number 2 (February-2018) • ISSN: 2349-8080 (Online) & \\
\hline $\begin{array}{l}\text { EXCELLENT } \\
\text { PUBLISHERS }\end{array}$ & Journal homepage: www.ijcrbp.com & \\
\hline
\end{tabular}

\title{
Spatiotemporal Variation of Phytoplankton Community Structure in the Crater Lake Barombi Kotto, Cameroon
}

\author{
Awo Miranda Egbe ${ }^{1}$, Pascal Tabi Tabot ${ }^{2 *}$, Nso Goodenough ${ }^{1}$ \\ and Fonge Beatrice Ambo ${ }^{1}$
}

\begin{abstract}
${ }^{1}$ Department of Botany and Plant Physiology, University of Buea, Cameroon 2Department of Agriculture, Higher Technical Teachers' Training College Kumba, University of Buea, Cameroon
\end{abstract}

${ }^{*}$ Corresponding author.

\begin{tabular}{|c|c|}
\hline Article Info & ABSTRACT \\
\hline $\begin{array}{l}\text { Date of Acceptance: } \\
13 \text { January } 2018\end{array}$ & \multirow{3}{*}{$\begin{array}{l}\text { Lake Barombi Kotto, the second largest crater lake of volcanic origin in Cameroon, is } \\
\text { unique in harbouring a large island community and surrounded by hilly landscape in } \\
\text { which agriculture is practiced. The high dependence of resident-and visiting } \\
\text { populations on this lake prompted an assessment of spatio-temporal dynamics of } \\
\text { phytoplankton in relation to abiotic and anthropogenic stressors. Samples were } \\
\text { collected in two seasons across a transect, and at two depths, and subjected to physico- } \\
\text { chemical, nutrient, chlorophyll a and phytoplankton analyses using standard methods. } \\
\text { Descriptions, Analyses of variance, ordinations and correlations were used to analyse } \\
\text { resulting data. Results showed that there were significant variations in ToxN and } \\
\text { Phosphorus concentrations, which partially drive the observed phytoplankton } \\
\text { patterns. There was seasonal and depth stratification, and species changes in some } \\
\text { divisions across seasons. The Euglenophycean Index showed that the lake was } \\
\text { perpetually eutrophic, with very high abundances of toxic Cyanophyta species that in } \\
\text { some cases form associations with Aulocoseira granulata. The inconclusivity of nutrients } \\
\text { and other abiotic factors as drivers of phytoplankton richness, abundance and } \\
\text { distribution suggest a contribution of anthropogenic factors. These results are } \\
\text { significant as they form the first stratified study of this lake that has enormous human } \\
\text { and ecological importance. }\end{array}$} \\
\hline Keywords & \\
\hline $\begin{array}{l}\text { Chlorophyll a biomass } \\
\text { Lake Barombi Kotto } \\
\text { Phytoplankton } \\
\text { Spatiotemporal variation } \\
\text { Toxic Cyanophyta species }\end{array}$ & \\
\hline
\end{tabular}

\section{Introduction}

Algae are non-embryonic, non-vascular, oxygenic photoautotrophs whose primary photoreceptive pigment is chlorophyll a. Aquatic algae inhabit a variety of environments, occupying various niches in a body of water. Phytoplankton are those suspended or free-swimming in open water, benthic algae are those embedded in substrate, organic matter or sediments, while epiphytic algae are those 
attached to aquatic plant surfaces (Bellinger and Siegee, 2010).

The phytoplankton community is an important biological component of water bodies, because it is responsible for a large part of the primary production and accounts for nearly $50 \%$ of the global net primary production (Salmaso et al., 2012). They are essential for biogeochemical cycles and form the base of aquatic food webs. Phytoplankton communities consist of a number of diverse species with different ecophysiological tolerances and morphological characteristics, resource requirements, growth rates, and sinking velocities (Reynolds 2006). Species composition of phytoplankton community is an efficient bioindicator of water quality (Fonge et al., 2015). Although their contributions to key ecological functions in aquatic systems are enormous, their excessive growth can also cause significant threats to local biodiversity and ecosystem functioning, as in the case of toxic algal blooms (Sanseverino et al., 2016).

Phytoplankton community structure and diversity have been shown to change with both biotic and abiotic factors with the most important factors influencing their distribution being salinity, size, depth, temperature, carbondioxide, transparency, dissolved oxygen, alkalinity and nutrients especially Nitrogen and Phosphorus (Ganai and Saltanat, 2014; Neale et al., 2014; Fonge et al., 2015; Anyinkeng et al., 2016; Tabot et al., 2016) thus the algal composition is, to some degree, a reflection of the condition of a body of water.

Combinations of physical, chemical and biotic features of natural waters function in a synergistic fashion to determine the sensitivity of water bodies and most importantly, this interaction determines the environmental heterogeneity, a key factor in determining the diversity and successional patterns of phytoplankton (Paerl et al., 2001). If consumption of plankton by grazers cannot keep pace with production, excess phytoplankton accumulates. Phytoplankton accumulation that leads to visible discoloration (mostly yellow, green, blue-green, red or brown) of the water is called blooms, which can occur on the surface or on specific depths corresponding to optimal light and nutrient levels as well as thermal and density stratification. In waters susceptible to blooms, human activities in watersheds have been linked to the extent and magnitudes of blooms. Such anthropogenic activities typically add nutrients to water bodies, which augment natural mineralization and thus create bloom-friendly conditions. The type and amount of nutrient input constraints depend on the hydrological, climatic, geographic, and geologic factors, which interact with anthropogenic and natural nutrient input regimes. From an ecosystem perspective, high rates of nutrient loading accompanied by water residence time long enough to support adequate growth and high reproductive rates, combined with relatively low grazing rates, represent optimal conditions for bloom development (Paearl et al., 2011).

Most phytoplankton are microscopic, hence it is difficult to quantify the population in terms of absolute numbers of individual algal cells. To get around this, photosynthetic pigments present in such organisms can be quantified in order to estimate the total biomass of algae present within a body of water. Chlorophyll a quantification is used as an indicator of the amount of photosynthetic material in water bodies.

Although Cameroon is endowed with abundant freshwater resources, water challenges in Cameroon are numerous. Studies from different parts of the country indicate that many water resources used for drinking purposes, recreation and agriculture are polluted to varying degrees either because waste disposal infrastructure is insufficient, and/or the capacity to enforce existing laws is very weak. As a result, anthropogenic nutrient enrichment mainly with nitrogen and phosphorus discharges around the water catchments and into water bodies is accelerating decline in water quality (Tening et al., 2014; Fonge et al., 2015; Tabot et al., 2016). This especially has serious implications in inland waters in areas without alternative portable water sources. 
Lake Barombi Kotto is a resource of great socioeconomic and ecological significance. It is a volcanic crater lake linked to the Mount Cameroon volcanic chain and is a habitat for many endemic and vulnerable plant and animal species including bacteria, fungi, algae, mussels, snails, crustaceans, insects, fish, amphibians, reptiles, birds and mammals (Moelants, 2010). Within the lake is an inhabited island, with other communities surrounding the lake all dependent on it for recreation, domestic uses and transport. Corbet et al. (1973) carried out an ecological survey in this lake and listed a few dominant phytoplankton species and prevailing physicochemical parameters. Tabi et al. (2015) focused on the Cyanobacteria in Lake Barombi Kotto to the exclusion of other algal groups. Other studies on this lake have focused on human health diseases like urinary schistosomiasis (Nkengazong et al., 2009). Little is documented on lake water quality dynamics and seasonal effects on phytoplankton assemblages in Lake Barombi Kotto. This study aimed to assess the seasonal and spatial variability of algal abundance and community composition in Lake Barombi Kotto, in relation to anthropogenic activities. Specific objectives included: 1) To assess the relationship between the amount of chlorophyll a, algal abundance and taxonomic composition of the community and 2) To determine the effects of physicochemical parameters on the dynamics of alga communities in Lake Barombi Kotto.

\section{Materials and methods}

\section{Description of study site}

Lake Barombi Kotto is a shallow fresh water crater lake located $100 \mathrm{~m}$ above sea level in a complex geological arrangement of volcanic rocks. It is found at $4^{\circ} 28^{\prime} \mathrm{N}$ and $9^{\circ} 16^{\prime} \mathrm{E}$ in Meme Division of the South West Region, Cameroon. It has a total surface area of 330 hectares and average depth of $3.8 \mathrm{~m}$ and a maximum depth of $6 \mathrm{~m}$. The maximum length of the lake is $2.2 \mathrm{~km}$ with a maximum width of $2 \mathrm{~km}$. It surrounds two islands, one of which is inhabited by the Barombi Kotto tribe. Surrounding the lake is another settlement of non-natives whose main occupation is farming and fishing. The total population of this community is about 4000 inhabitants (Ndamukong et al., 2001). Lake waters collect into a basin surrounded by hilly terrain on all sides, and with a conical island at the middle. With the lake as the lowest point all round, this relief facilitates leaching and runoff from all directions into the lake. The main water input into this lake is from an inflowing stream called Tung Nsuria which is the main source of drinking water in this community. This lake empties into River Meme through the outflowing stream called Nkondong. There are two main seasons; the Rainy season (March-October) and a Dry season (November-February).This lake supports a lot of socio economic activities like fishing, tourism, swimming and laundry, providing water for drinking (inlet) and domestic chores. Farmers fetch water from this lake to mix agrochemicals for the spraying of cocoa and other agricultural crops.

For the purpose of this study, 8 representative sampling points were selected along a diagonal across the lake to capture sources of inputs and sinks in the centre of the lake, at the leading and backward face of the lake (Fig. 1). The names and geographic coordinates of the sites are presented in Table 1.

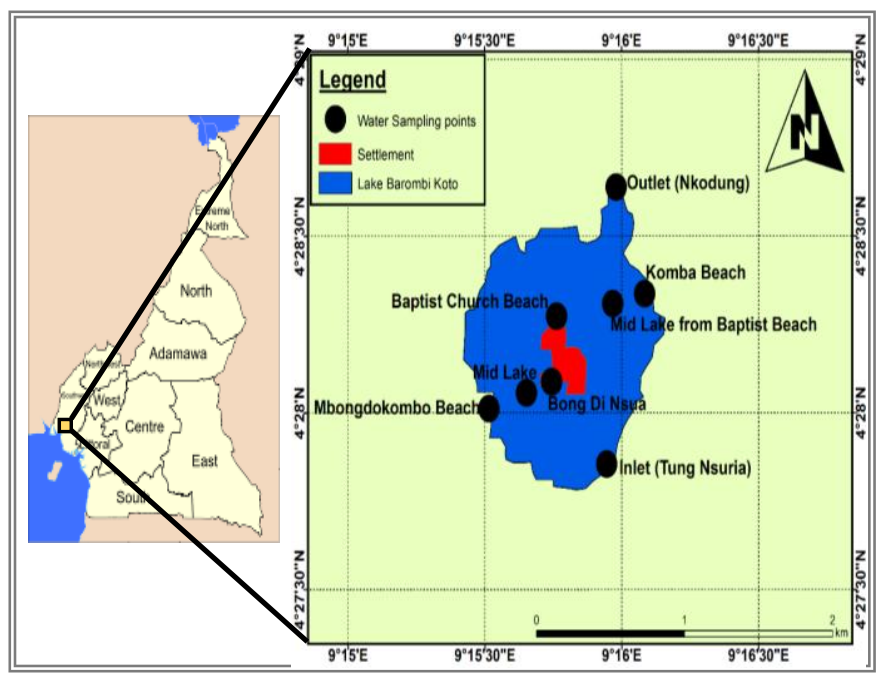

Fig. 1: Map showing study site and sampling points. 
Table 1. Sampling points and GPS coordinates.

\begin{tabular}{|c|c|c|c|c|}
\hline Site & Description & Coordinates & & \\
\hline S1 & Mbongdokombo Beach & $04^{0} 28^{\prime} 00.7^{\prime \prime} \mathrm{N}$ & $009^{0} 15^{\prime} 30.9^{\prime \prime} \mathrm{E}$ & 87 \\
\hline $\mathrm{S} 2$ & Mid Lake & $04^{0} 28^{\prime} 03.4^{\prime \prime} \mathrm{N}$ & $009^{0} 15,39.1$ " E & 88 \\
\hline S3 & Bong Di Nsua & $04^{0} 28^{\prime} 05.3^{\prime \prime} \mathrm{N}$ & $009^{0} 15,44.6 " \mathrm{E}$ & 89 \\
\hline S4 & Baptist Church Beach & $04^{0} 28^{\prime} 16.4^{\prime \prime} \mathrm{N}$ & $009^{0} 15^{\prime} 45.7 ” \mathrm{E}$ & 99 \\
\hline S5 & Mid Lake on the backward face & $04^{0} 28^{\prime} 18.5^{\prime \prime} \mathrm{N}$ & $009^{0} 15^{\prime} 58.0^{\prime \prime} \mathrm{E}$ & 89 \\
\hline S6 & Komba Beach & $04^{0} 28^{\prime} 20.2^{\prime \prime} \mathrm{N}$ & $009^{0} 16^{\prime} 05.0^{\prime \prime} \mathrm{E}$ & 91 \\
\hline S7 & Inlet (Tung Nsuria) & $04^{0} 27^{\prime} 51.3^{\prime \prime} \mathrm{N}$ & $009^{0} 15,56.7^{\prime \prime} \mathrm{E}$ & 90 \\
\hline S8 & Outlet (Nkondung) & $04^{0} 28^{\prime} 38.3^{\prime \prime} \mathrm{N}$ & $009^{0} 15^{\prime} 58.8^{\prime \prime} \mathrm{E}$ & 87 \\
\hline
\end{tabular}

\section{Conceptual framework}

Lake Barombi Kotto is circular, with a conical island settlement at the middle, and surrounded by hilly terrain. There are beaches on several sites along settlements, and farmland. Sites were selected to cover the points of land use intensity. From the main settlement before the lake, Site 1 represents a beach with intensive laundry activities. Site 2 represents the deepest and hence sink site from this point. Site 3 is a beach on the front face, at the island, subject to domestic use. Site 4 is a beach at the backward face of the island, also characterized by laundry and domestic uses. Site 5 is central on this face of the lake and deeper than site 4, and Site 6 which is a beach at a cocoa farm. Sites 7 and 8 represent the inlet, assumed to have pristine waters, and outlet respectively. These sites thus represent all anthropogenic pressure points. Sampling was done at two depths, to capture possible effects of stratification, and across two seasons to capture temporal effects.

\section{Sample collection}

Samples were collected at 8 sites on Lake Barombi Kotto during the rainy season (August 2016) and the dry season (February 2017). At each point, samples were collected from two depths namely top $(\mathrm{D} 1=$ top $10 \mathrm{~cm})$ and bottom $(\mathrm{D} 2=3 \mathrm{~m}$ below the surface) using a Van Dorn sampler. The sampling sites are presented on Figure 1, with Geographical coordinates recorded using Garmin E-trex (Table 1).

At each sampling point, 2 sets of samples were collected in duplicates (for chlorophyll a analysis and phytoplankton analysis). Water temperature and transparency were taken in situ using the water thermometer and Secchi disk respectively, while other physicochemical parameters like Dissolved oxygen, conductivity, $\mathrm{pH}$, Total Dissolved Solids were determined in the Soil and Water Laboratory of the University of Dschang, Cameroon. Samples were transported to this laboratory in ice boxes.

\section{Chlorophyll a analysis}

Samples were kept on ice immediately following collection and during transport. In the lab, 200ml portions of each sample were run through $\mathrm{GF} / \mathrm{F}$ $0.47 \mu \mathrm{m}$ diameter filters, the filters were cut into small pieces and placed in a glass tube to which 10 $\mathrm{ml}$ of a buffered acetone solution were added. After 24 hours, this mixture was ground to a homogeneous slurry which was centrifuged at 2,100 rpm for 10 minutes to separate the solution from the filter paper. Chlorophyll-a absorbance was then determined using 722s Spectrophotometer (BBRAN Scientific Instrument Company, England) at $665 \mathrm{~nm}$ before and after acidification with $0.1 \mathrm{M}$ $\mathrm{HCl}$ for 2minutes. Chlorophyll a was calculated using the formula by Talling and Driver (1961).

\section{Phytoplankton enumeration and identification}

One litre of water collected at each sampling point for phytoplankton analysis was treated with three drops of $10 \%$ Lugol's iodine and transported in coolers containing ice to the Life Sciences Laboratory of the University of Buea for phytoplankton analysis. The wet mount method was used. Slides of each sample were prepared in triplicate. A drop of well-mixed sample was placed on a sterilized slide, covered with a cover slip and 
observed under the Olympus light microscope. Phytoplankton species were identified and counted by the use of a binocular light microscope (Olympus BH2), at a magnification of 100 and $400 x$. Identification was through comparative morphology and description using relevant text books, manuals and articles (Nguetsop et al., 2007; Bellinger and Siegee, 2010). Algae were classified according to algaebase.org.

\section{Nutrient and heavy metal analyses}

The levels of total dissolved solid (TDS), electrical conductivity (EC), dissolved oxygen (DO), $\mathrm{pH}$ were determined using standard procedures. Chemical parameters and nutrients were analysed in the University of Dschang Laboratory: Dissolved Bicarbonate $\left(\mathrm{HCO}_{3}^{-}\right)(\mathrm{mg} / \mathrm{l})$, Nitrogen-Nitrate $(\mathrm{N}-$ $\left.\mathrm{NO}_{3}-\right)$, Nitrite Nitrogen $\left(\mathrm{NO}_{2}-\mathrm{N}\right)$, ammonium nitrogen $\left(\mathrm{NH}_{4}-\mathrm{N}\right)$, Orthophosphate $\left(\mathrm{PO}_{4}{ }^{3-} \mathrm{P}\right)$, Total $\mathrm{P}$. For the main ions: Zinc $(\mathrm{Zn})$, Calcium $\left(\mathrm{Ca}^{2+}\right)$, Magnesium $(\mathrm{Mg})$, Potassium $\left(\mathrm{K}^{+}\right)$and for the Heavy metals: Iron $\left(\mathrm{Fe}^{2+}\right), \mathrm{Mn}\left(\mathrm{Mn}^{2+}\right)$, Copper $\left(\mathrm{Cu}^{2+}\right)$, Zinc $\left(\mathrm{Zn}^{2+}\right)$, Lead $\left(\mathrm{Pb}^{2+}\right)$ and Cadmium $\left(\mathrm{Cd}^{2+}\right)$. All analyses were done using standard methods (Murphy and Riley 1962; Cottenie et al., 1982; van Reeuwijk, 2002; APHA, 2005).

\section{Data analysis}

The abundance of each alga per milliliter was obtained from the sum of its occurrences in the three slides (drops) as follows:

\section{Abundance $(m l)=\frac{n 1+n 2+n 3}{0.15}$}

Where; $\mathrm{n} 1 \ldots \mathrm{n} 3=$ algal counts in drops; $0.15=$ volume of three drops in $\mathrm{ml}$. This was then converted to concentrations per litre.

Fishers alpha diversity index was calculated using an online Javascript tool according to the Newton's Method (Available at www.http://groundvegetation db-web.com/ground_veg/home/diversity_index), which is based on Fisher et al. (1943), Poole (1974), and Magurran (1981).
The Eutrophication Index was calculated as follows:

$$
E I=\frac{\text { Number of Euglenophyta }}{\text { Number of Cyanophyta }+ \text { number of chlorophyta }}
$$

When EI $<1$, the sample is Eutrophic and if $>1$, the sample is Oligotrophic.

Differences of physico-chemical parameters, nutrients and heavy metals across seasons and sampling stations were tested using ANOVA with Turkey HSD test at $\alpha=0.05$.

To investigate the relationships between phytoplankton community structure and environmental parameters, simple correspondence analysis and correlations were performed. Analyses of variance and ordinations were performed using the Minitab version 2017 statistical package (Minitab Inc., USA).

\section{Results}

\section{Visual observations}

The water was characteristically slow-flowing and turbid, with the colour characteristically bluish green. Colonies of algae aggregated into ball-like structures could be seen in suspension all across the lake, irrespective of the sampling site. At the bottom there were higher concentrations of these aggregates compared to the surface. In addition to these aggregates, a greenish scum could be observed at Site 1 where there was intensive laundry and sewage disposal (from soiled clothing). The floating aggregates of algae were also found at the inlet, which is expected to be pristine. Analyses of the composites showed they consisted of Microcystis species plus species of Aulocoseira granulosa.

\section{Physico-chemical parameters}

Physicochemical parameters considered in this study included temperature, $\mathrm{pH}$, conductivity, Secchi depth. Water temperature ranged from $20^{\circ} \mathrm{C}$ 
$-25^{\circ} \mathrm{C}$ in both seasons while conductivity varied significantly across sites and depths in the rainy season with maximum values ranging between 0.56-1.59 units at S5, S3, S4 and S6 and least values obtained in S1, S2 and S7. There was also a significant variation in conductivity with depths in the study with higher conductivities at the bottom (D2) than at the surface waters (D1). $\mathrm{pH}$ ranged between 7.3 to 7.54 (neutral $\mathrm{pH}$ ) with no significant variations across seasons, the different sites and depths. Higher values were recorded for Secchi depth in the rainy season $(0.62 \mathrm{~m})$ than in the dry season $(0.38 \mathrm{~m})$. The water of Lake Barombi Kotto can thus generally be described as fresh, neutral and very turbid especially in the dry season.

\section{Nutrients}

Table 2 shows the analysis of variance results for chlorophyll a, Total oxidizable nitrogen, phosphorus, hardness and dissolved oxygen, across sites, depth and seasons as the main effects. There were significant variations in chlorophyll a and ToxN for all factors and interactions. Phosphorus varied significantly with all main effects and interactions except the interaction between seasons and depths, while dissolved oxygen concentrations were only significantly different across seasons.

Table 2. Analysis of variance for chlorophyll, nutrients, hardness and dissolved oxygen across sites, seasons and depth.

\begin{tabular}{|c|c|c|c|c|c|c|c|}
\hline & Chl a & ToxN & Bicarbonates & TDS & Phosphorus & $\begin{array}{l}\text { Total } \\
\text { Hardness }\end{array}$ & DO \\
\hline Seasons & $* *$ & $* *$ & $* *$ & ns & $* *$ & $* *$ & $* *$ \\
\hline Site & $* *$ & $* *$ & $* *$ & $* *$ & $* *$ & $* *$ & ns \\
\hline Depth & $* *$ & $* *$ & ns & $* *$ & $* *$ & $* *$ & ns \\
\hline Seasons $*$ Site & $* *$ & $* *$ & $* *$ & ns & $* *$ & $* *$ & ns \\
\hline Seasons*Depth & $* *$ & $* *$ & $\mathrm{~ns}$ & ns & ns & ns & ns \\
\hline Site*Depth & $* *$ & $* *$ & ns & $* *$ & $* *$ & $* *$ & ns \\
\hline Site*Depth*Seasons & $* *$ & $* *$ & $* *$ & ns & $* *$ & $* *$ & ns \\
\hline
\end{tabular}

$* *=$ Significant variation; ns= Not Significant.

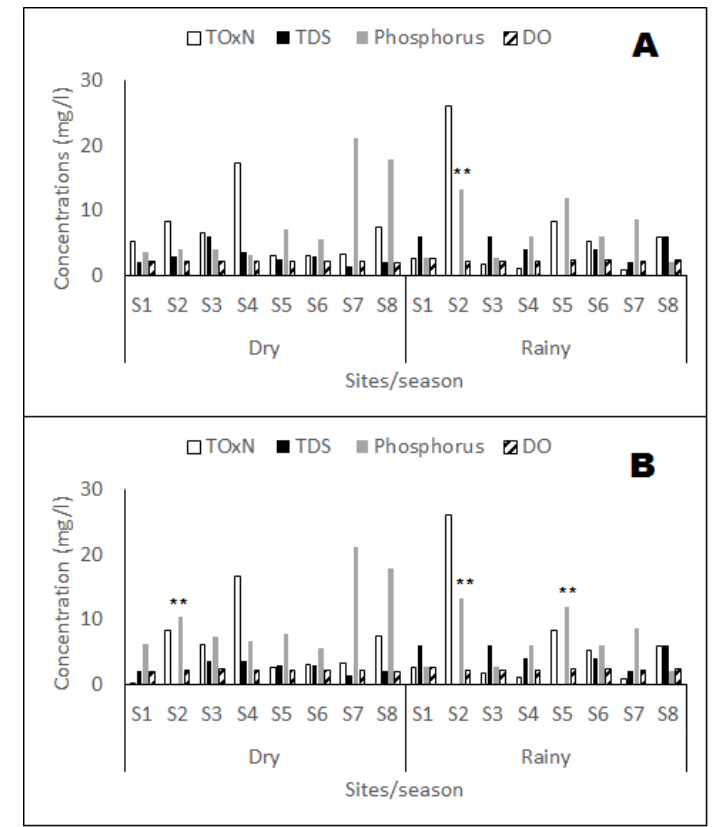

Fig. 2: Seasonal concentration of nutrients, dissolved solids and dissolved oxygen across sites. A = Surface waters; $\mathrm{B}=$ bottom waters; $* *=$ sites for which TDS values were excluded because they were several degrees above scale.
The seasonal concentrations of nutrients, dissolved solids and DO are presented in Fig. 2.

\section{Total oxidizable nitrogen (ToxN)}

In surface waters, ToxN ranged from $2.99 \mathrm{mg} / \mathrm{l}$ in $\mathrm{S} 5$ to $17.3 \mathrm{mg} / \mathrm{l}$ in $\mathrm{S} 4$ in the dry season. Patterns in the other sites were of the order S2> $\mathrm{S} 4>\mathrm{S} 8>\mathrm{S} 3>\mathrm{S} 5>\mathrm{S} 6>\mathrm{S} 1>\mathrm{S} 7$. ToxN concentrations in the rainy season ranged from $0.84 \mathrm{mg} / \mathrm{l}$ in $\mathrm{S} 7$ to $26.09 \mathrm{mg} / 1$ in $\mathrm{S} 2$. Significant differences $(p<0.05)$ occurred between sites in the following order: $\mathrm{S} 2>\mathrm{S} 5>\mathrm{S} 8>\mathrm{S} 6>\mathrm{S} 3>\mathrm{S} 1>\mathrm{S} 4>\mathrm{S} 7$ (Fig. 2). In bottom waters, ToxN concentrations ranged from $0.09 \mathrm{mg} / 1$ in $\mathrm{S} 1$ to $16.59 \mathrm{mg} / \mathrm{l}$ in $\mathrm{S} 4$ in the dry season, and 0.84 to $26.09 \mathrm{mg} / \mathrm{l}$ in $\mathrm{S} 7$ and $\mathrm{S} 2$ respectively in the rainy season. Consistently there were higher ToxN concentrations in S2 for both depths and across seasons. Fig. 3 illustrates the interaction plot for ToxN and phosphorus concentrations across seasons, sites and depths. The statistical 
significance of these interactions is illustrated in Table 2. ToxN concentrations were highest in Site 2 for the bottom samples and decreased across the rest of the sites irrespective of depth. With respect to seasonal effects, ToxN concentrations were highest in Site 2 in the rainy season and Site 4 in the dry season (Fig. 3).

\section{Phosphorus}

Phosphorus concentrations ranged from $3.24 \mathrm{mg} / \mathrm{L}$ in S4 to $21.12 \mathrm{mg} / \mathrm{l}$ in $\mathrm{S} 7$ in the dry season and from $2.0 \mathrm{mg} / \mathrm{L}$ in $\mathrm{S} 8$ to $13.34 \mathrm{mg} / \mathrm{L}$ in $\mathrm{S} 2$. Sites differed from each other in phosphorus concentrations. In the rainy season, higher concentrations occurred in S2 and S5 which are sites located in the middle of the lake and also in S7, the in-flowing stream into the lake Barombi Kotto. S5 and S6 which also had high concentrations are sites close to agricultural farmlands. Mean phosphorus concentration in D2 $(6.70 \mathrm{mg} / \mathrm{L})$ were significantly greater $(p<0.05)$ than that of D1 $(4.51 \mathrm{mg} / \mathrm{L})$, suggesting nutrient accumulation in the bottom of the lake. Seasonal trend of phosphorus concentration across sites and depths is illustrated in Fig. 2. Fig. 3 presents interaction effects on phosphorus concentrations, and shows that there were higher concentrations in the bottom samples irrespective of site, higher concentrations in the dry season especially at Site 7.
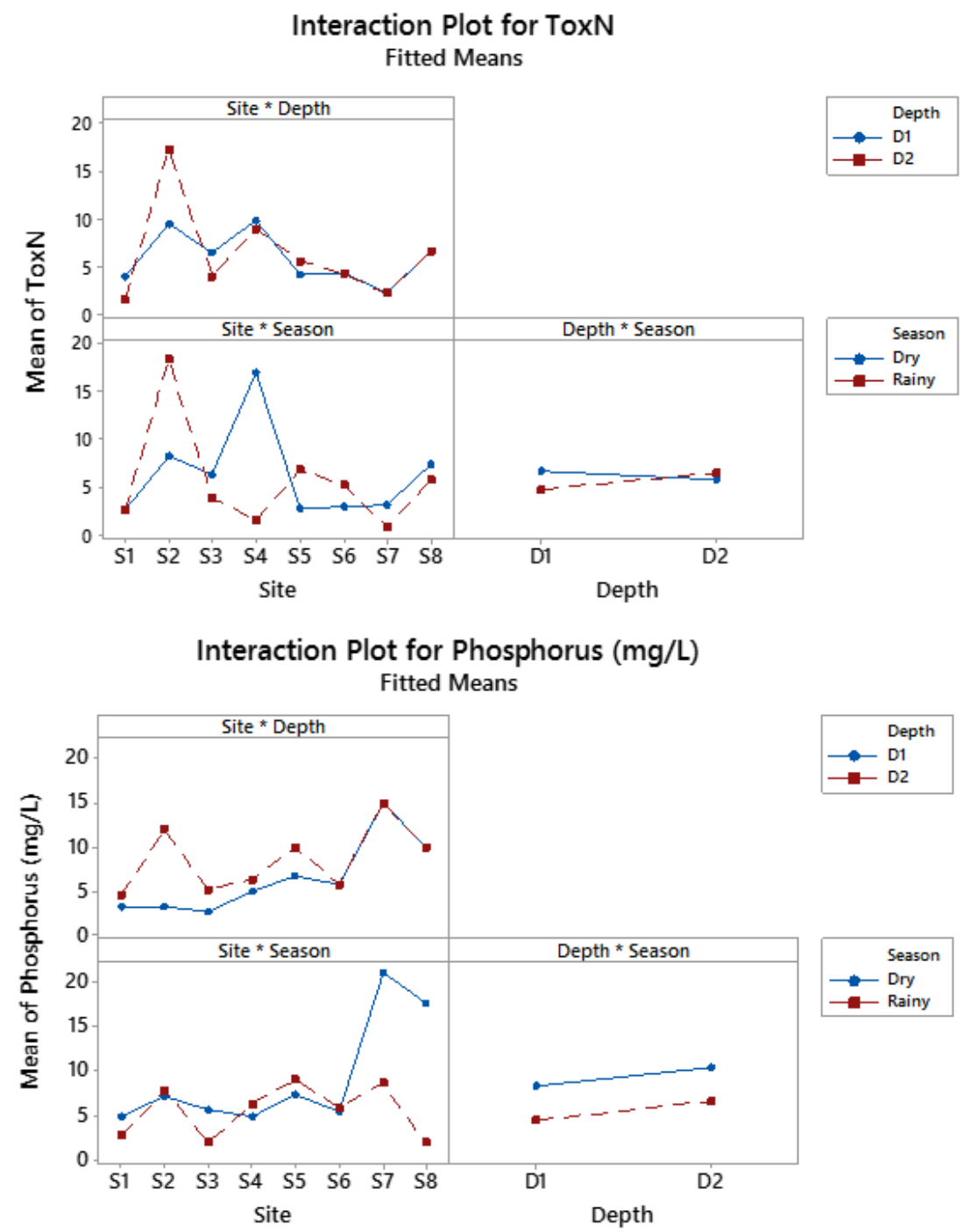

Fig. 3: Interaction Plot for ToxN and Phosphorus concentrations in the samples across sites, seasons and depths. 


\section{Bicarbonate (mg/CaCO$)$}

Significant variations in bicarbonate concentrations (data not shown) occurred in the dry season across the different sites and depths ranging from 20.61 $\mathrm{mg} / \mathrm{L}$ in $\mathrm{S} 4$ to $36.60 \mathrm{mg} / \mathrm{L}$ in $\mathrm{S} 8$.

Total hardness $\left(\mathrm{mg} / \mathrm{CaCO}_{3}\right): \quad$ Significant variations were recorded across seasons, the different sites and depths (Table 2). Mean total hardness ranged from $29.55 \mathrm{mg} / \mathrm{CaCO}_{3}$ in $\mathrm{S} 1$ to $43.15 \mathrm{mg} / \mathrm{CaCO}_{3}$ in $\mathrm{S} 2$ with the mid lake sites ( $\mathrm{S} 2$ and S5) having highest mean total hardness than all the other sites in the rainy season. In the dry season, total hardness ranged from 17.8 in $\mathrm{S} 7$ to $72.25 \mathrm{mg} / \mathrm{L}$ in S5 and the accumulation was in the following order: S5 > S8 > S4 >S2, S6, S1>S3>S7. Sites along the agricultural farmlands had significantly higher total hardness and also significantly higher hardness at D2.

\section{TDS}

Total dissolved solutes concentrations varied across sites and depth but there were no seasonal effects. Concentrations typically ranged from 2 to $6 \mathrm{mg} / \mathrm{l}$, with notable exceptions; in the surface waters, TDS concentrations at Site S2 in the rainy season were $9745 \mathrm{mg} / \mathrm{l}$, and in the bottom samples, TDS in S2 was $5105 \mathrm{mg} / \mathrm{l}$ in the dry season and 9745 and $400 \mathrm{mg} / \mathrm{l}$ in sites S2 and S5 respectively in the rainy season. Sites 2 and 5 are the mid lake sites in the front and back faces of the lake respectively.

\section{Dissolved oxygen (DO)}

Dissolved Oxygen varied significantly across seasons but no significant variations occurred at different sites and depth (Table 2). Mean DO concentrations ranged from $2.29 \mathrm{mg} / \mathrm{L}$ to $2.56 \mathrm{mg} / \mathrm{L}$ in the rainy season, while in the dry season, it had the range of $1.99-2.3 \mathrm{mg} / \mathrm{L}$ significantly higher than that in the dry season (Fig. 2).

\section{Heavy metals}

Tests of significance results on heavy metals concentrations across sites are presented in Table 3. Of the 5 heavy metals assessed in this study, there were significant variations of heavy metals concentrations across seasons only for $\mathrm{Fe}, \mathrm{Cu}$ and $\mathrm{Mn}$. No seasonal variation was recorded for $\mathrm{Zn}, \mathrm{Pb}$ and $\mathrm{Cd}$. Only $\mathrm{Fe}, \mathrm{Zn}$ and $\mathrm{Cu}$ contents varied significantly across different sites $(p \leq 0.05)$.

Table 3. Heavy metals across sites, seasons and depth sites seasons and depth in Lake Barombi Kotto.

\begin{tabular}{|c|c|c|c|c|c|c|}
\hline & $\mathrm{Fe}$ & $\mathrm{Zn}$ & $\mathrm{Cu}$ & $\mathrm{Mn}$ & $\mathrm{Pb}$ & $\mathrm{Cd}$ \\
\hline Seasons & ** & ns & $* *$ & ** & ns & ns \\
\hline Site & $* *$ & $* *$ & $* *$ & ns & ns & ns \\
\hline Depth & ** & ns & $\mathrm{ns}$ & ns & ns & ns \\
\hline Seasons * Site & $* *$ & $* *$ & ** & $* *$ & ns & ns \\
\hline Seasons*Depth & ** & ns & $\mathrm{ns}$ & ns & ns & ns \\
\hline Site*Depth & ** & ns & $\mathrm{ns}$ & ns & ns & ns \\
\hline Site*Depth*Seasons & $* *$ & ns & ns & ns & ns & ns \\
\hline
\end{tabular}

For Iron $(\mathrm{Fe})$, the mean concentration in the rainy season ranged from $2.638 \pm 0.131$ to $2.875 \pm 0.054$ $\mathrm{mg} / \mathrm{l}$. For the dry season, mean Fe concentration ranged from $3.04 \pm 0.315 \mathrm{mg} / \mathrm{l}$ in $\mathrm{S} 7$ to $6.615 \mathrm{mg} / \mathrm{l}$ in S8 with the following pattern: S8>S4>S2>S3 $>$ S6, with higher values in the sites along the agricultural farmlands.

For Zinc ( $\mathrm{Zn})$, there was a significant variation across sites with mean $\mathrm{Zn}$ concentration ranging between $0.01 \mathrm{mg} / \mathrm{l}-0.028 \mathrm{mg} / \mathrm{l}$ in $\mathrm{S} 4$ and $\mathrm{S} 5$ respectively in the rainy season. Higher levels of $\mathrm{Zn}$ were found at mid lake from the agricultural wing at $\mathrm{S} 5$ and $\mathrm{S} 6(0.028 \mathrm{mg} / \mathrm{l})$ and also inland from the Island beach at S3 and S2. In the dry season, significant variations across sites but not across depth were recorded, with S3 and S4 having maximum concentrations of 0.56 and $1.79 \mathrm{mg} / \mathrm{l}$ respectively. The inland beaches (around the island settlement) had higher zinc content in the dry season. For $\mathrm{Cu}$, there were significant variations across seasons, with mean $\mathrm{Cu}$ concentration for the rainy season significantly higher than the dry season. Manganese (Mn), Lead $(\mathrm{Pb})$ and Cadmium $(\mathrm{Cd})$ contents exhibited no significant variations across seasons, sites and depths (Table 3). 


\section{Phytoplankton biomass measured as chlorophyll a concentration}

Tests of significance on chlorophyll a concentration are presented in Table 2. Chlorophyll concentrations varied significantly with depth, sites and seasons as well as all interactions. Fig. 4 illustrates the concentration of chlorophyll a across sites (A), Depths (B) and seasons (C).

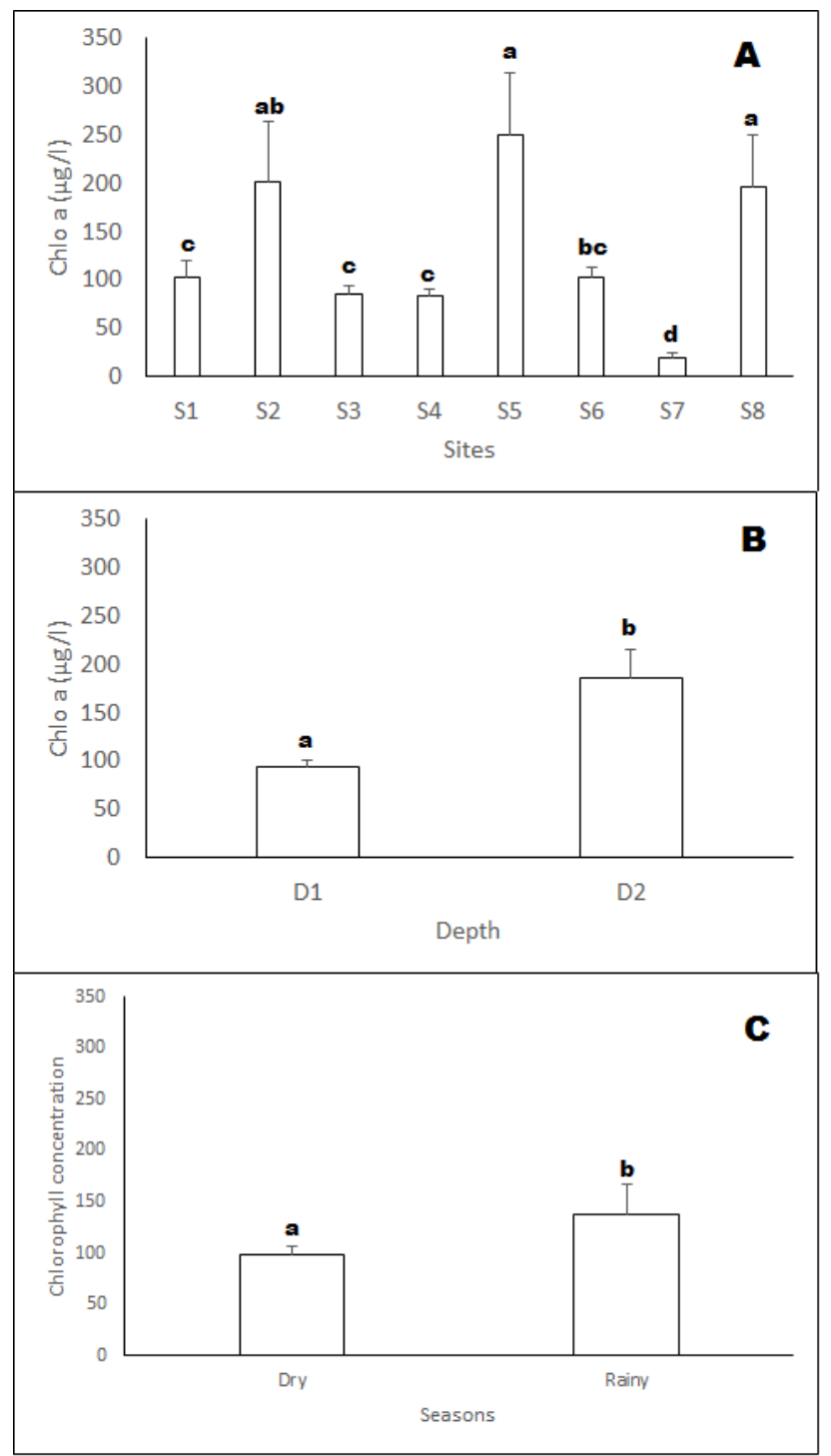

Fig. 4: Chlorophyll $a$ concentration across sites (A), depth (B) and seasons (C) in Lake Barombi Kotto.

Mean chlorophyll a concentration was higher in Sites 2, 5 and 8 (201.2, 250.5 and $196.9 \mu \mathrm{g} / \mathrm{l}$ respectively). There were significantly higher mean chlorophyll a concentration at the bottom water, D2
$(185.9 \pm 314)$ than the surface waters D1 $(93.8 \pm$ 11.0) (Fig. 4). Also, there were higher chlorophyll a concentrations in the rainy season $(139 \mathrm{mg} / \mathrm{l})$ than in the dry season $(98.8 \mathrm{mg} / \mathrm{l})$. The lowest mean concentration of chlorophyll a was recorded in Site 7 (19.15 \pm 3.85). There was a general increase in mean chlorophyll a concentration in all the sites (except mid-lake sites S5 and S2) during the dry season. In both seasons, S5 had the highest concentration of chlorophyll a. The order of chlorophyll a concentration in the different sites was as follows:

Dry season: $\mathrm{S} 5>\mathrm{S} 1>\mathrm{S} 2>\mathrm{S} 6>(\mathrm{S} 8$ and $\mathrm{S} 3)>\mathrm{S} 4$ $>$ S7 (Fig. 4)

Rainy season: $\mathrm{S} 5>\mathrm{S} 8>\mathrm{S} 2>\mathrm{S} 6>\mathrm{S} 4>\mathrm{S} 3>\mathrm{S} 1>\mathrm{S} 7$.

\section{Phytoplankton community structure and seasonal dynamics}

A total of 8 algal divisions were identified in Lake Barombi Kotto during the study period namely Bacillariophyta,Chlorophyta, Chrysophyta, Cryptophyta, Cyanophyta,Dinophyta, Euglenophyta, and Xanthophyta. There were marked seasonal and spatial differences in the quantitative and qualitative composition of phytoplankton. The divisions Chlorophyta and Cyanophyta had more species in the dry season, and in the rainy season the Chlorophyta and Bacillariophyta had more species compared to all other divisions (Fig. $5 \mathrm{~A}$ and $\mathrm{B}$ ). The Division Cyanophyta witnessed a marked drop in number of species in the rainy season compared to the dry season (Fig. 5A and $\mathrm{B}$ respectively). The Euglenophytas which are indicators of oligotrophic conditions were relatively fewer compared to the Chloropyta and Cyanophyta that would thrive in eutrophic conditions. The Euglenophycean Index was markedly $<1$ in both seasons, indicating that the waters were eutrophic throughout and for both surface and bottom waters. In terms of abundance (Figures 5C and D) the Cyanophyta were more abundant in both seasons, with a significantly higher percentage in the Dry season. The relative abundance of the Chlorophyta also increased in the Rainy season (from 6 to 13\%) as did relative abundances of Dinophyta and Euglenophyta. 

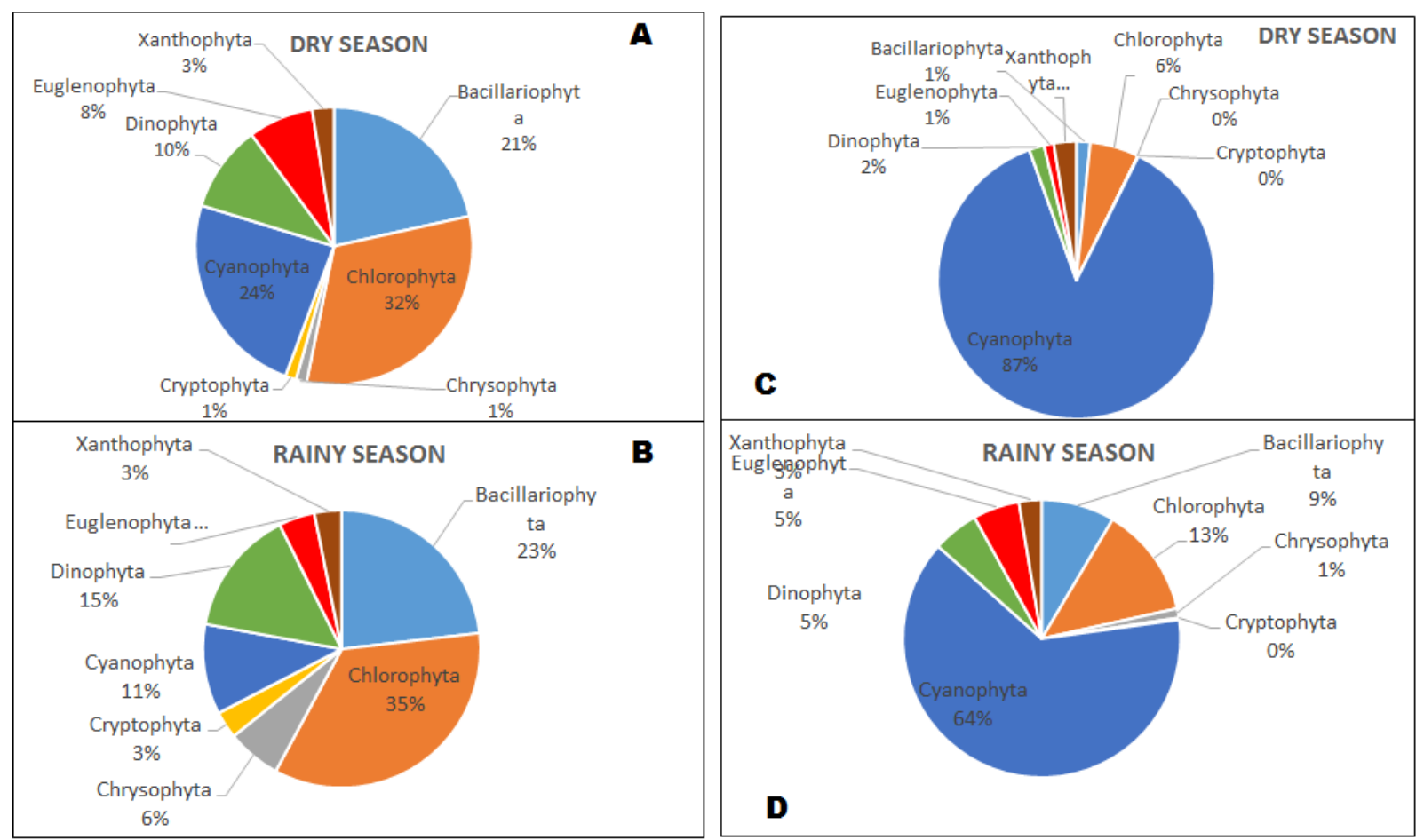

Fig. 5: Phytoplankton community structure and seasonal dynamics in the Lake Barombi Kotto.

Phytoplankton community composition (species richness) varied significantly across sites and depths in the rainy season with Chlorophyta, Cyanophyta and Dinophyta recorded as the 3 most abundant divisions (Figure $5 \mathrm{~A}$ and $\mathrm{B}$ ). Chlorophyta had the highest percent composition in most of the sites $(\mathrm{S} 1=53 \%) \quad \mathrm{S} 2=36 \%$ and $\mathrm{S} 8=38 \%)$. Dinophyta dominated in S7 (54\%), S8 (48\%) and S3 (49\%) and Chlorophyta recorded highest (41\%, $31 \%$ and $20 \%$ ) in S1, S2 and S6 respectively.

At the lower depth (D2), 4 major Divisions had high percent composition; namely Bacillariophyta, Chlorophyta, Cyanophyta and Dinophyta. The abundance of Bacillariophyta was higher in D2 than in D1 for the rainy season. The proportion of Bacillariophyta in surface samples at site 1 increased from $4 \%$ to $51 \%$ in $\mathrm{D} 2,21 \%$ to $28 \%$ in $\mathrm{S} 2,7 \%$ to $18 \%$ in S3, $0 \%$ to $32 \%$ in S5. Xanthophyta had a higher percent composition in S2. Some taxa were found to occur only in one depth and not in the other. For example, Chrysophyta, Cryptophyta and Xanthophyta were present in the rainy season (both D1 and D2) but in the dry season, these 3 divisions occurred only in the bottom samples.
In the Dry season, bloom concentrations were recorded for the Cyanophyta, Dinophyta and Chlorophyta. Cyanophyta was most abundant in 3 sites S4 (86\%), S5 (76\%) and S6 (44\%) followed by Dinophyta which was most abundant in $\mathrm{S} 7$ (82\%), S8 (58\%) and S3 (50\%) and Chlorophyta which was most abundant in S1(41\%), S2 (31\%) and S8 (18\%). In the bottom samples during the Dry season, Cyanophyta, Dinophyta and Bacillariophyta are the most abundant taxa.

\section{Spatial and temporal variation in species richness and diversity}

Phytoplankton species composition differed significantly across sites, depths and seasons. Overall, species richness was similar, though higher for surface waters in the rainy season and for bottom waters in the dry season (Table 4). Surface waters lost 13 species in the dry season compared to the rainy season, while bottom waters gained 4 species in the dry season compared to the rainy season. Irrespective of species, phytoplanktons were more abundant in the dry season, with higher abundance in the bottom 
waters (Table 4). In the rainy season, there is also a vertical stratification of phytoplankton abundance, as more individuals were enumerated from the bottom samples. The most diverse season (Fishers $\alpha=6.008$ ) was the surface samples at the rainy season. With respect to spatial dynamics, Sites 3 and 1 had greater abundance, richness and diversity in the rainy season for the front face of the lake, compared to the middle site (S2). At the back end of the lake, the middle site (S3) had greater abundance but less richness and diversity compared to the two other sites on this face (S4 and S6) in the rainy season. In the dry season for the front end of the lake, the middle site (S2) had a higher abundance, species richness and diversity compared to Sites 1 and 3 and this pattern of accumulation towards the middle of the lake was also observed at the back face of the lake where the middle site (S5) had greater abundance, richness and diversity in the dry season (Table 4).

Table 4. Phytoplankton Abundance, Species Richness and Diversity across seasons and depths in Lake Barombi Kotto.

\begin{tabular}{lllll}
\hline Temporal variations & & & & \\
\hline Season & Depth & Abundance & Richness (S) & Fishers $\boldsymbol{\alpha}$ \\
Rainy & D1 & $7,090,000$ & 84 & 6.008 \\
Dry & D1 & $17,760,863$ & 71 & 4.687 \\
Rainy & D2 & $10,546,667$ & 80 & 5.532 \\
Dry & D2 & $26,899,984$ & 84 & 5.450
\end{tabular}

\begin{tabular}{lllllll}
\hline \multicolumn{2}{l}{ Spatial variations } & & & & \\
Site & $\begin{array}{l}\text { Abundance } \\
\text { Rainy season }\end{array}$ & Dry Season & $\begin{array}{l}\text { Richness }(\mathbf{S}) \\
\text { Rainy Season }\end{array}$ & Dry Season & $\begin{array}{l}\text { Fishers } \boldsymbol{\alpha} \\
\text { Rainy Season }\end{array}$ & Dry Season \\
\hline S1 & $1,255,000$ & $3,083,333$ & 36 & 29 & 2.764 & 2.038 \\
S2 & $1,066,667$ & $4,244,910$ & 34 & 40 & 2.633 & 2.811 \\
S3 & $1,438,333$ & $2,080,392$ & 40 & 28 & $\mathbf{3 . 0 6 2}$ & 2.022 \\
S4 & 875,000 & $2,026,667$ & 38 & 40 & 3.022 & 2.978 \\
S5 & $1,315,000$ & $2,223,333$ & 27 & 43 & 2.017 & $\mathbf{3 . 1 9 6}$ \\
S6 & 971,667 & $1,208,333$ & 28 & 34 & 2.150 & 2.606 \\
S7 & $1,033,333$ & $2,970,080$ & 14 & 12 & 1.011 & 0.792 \\
S8 & 863,333 & $4,493,333$ & 14 & 13 & 1.026 & 0.839 \\
\hline
\end{tabular}

\section{Dynamics within major divisions}

\section{Division Bacillariophyta}

In Bacillariophyta, a total of 13 diatom species from 12 families were recorded in all the 8 sites in surface waters (D1) during the rainy season. These species were Aulacoseira granulata, Nitzchia palea, Cocconeis pediculus, Cymbella sp, Synedra ulna, Peronia sp, Pinnularia sp, Pinnularia viridis, Rhizosolenia bergonii, $U$. eriensis, Cyclotella meneghiniana, Cymatopleura sp, Tabellaria flocculosa. Of these, only 6 species represented in 4 families were present in the Dry season namely Aulacoseira granulata, 2 species of Cocconeis, Rhizosolenia sp, and 2 species of Cyclotella. Species richness increased with depth; 16 diatom species were present in D2 as opposed to 13 in D1 in the rainy season while in the dry season, 20 species were present in D2 as opposed to 6 in D1.

\section{Division Chlorophyta}

Chlorophyta exhibited a very high diversity and species richness in the rainy season. Twenty-eight species of green algae from 15 families were present in the surface water (D1) in the rainy season but in the dry season only 15 species from 7 families were present. Some species were only present in the rainy season and not in the dry season, for instance Stigeoclonium sp, Cladophora fracta, Closterium sp, Cosmarium sp, Micrasterias sp, Staurodesmus sp, Chlorogonium sp, Haematococcus sp, Micractinium sp, Golenkinia 
sp, Oedegonium sp, Tetrastrum sp, Selenastrum sp, Synura sp, Mougeotia sp, Spirogyra sp and Zygnema sp. Seven species of green algae were unique only to the dry season (Ankyra sp, Dictyosphaerium sp, Pediastrum duplex, Pediastrum simplex, Scenedesmus quadricauda, Pandorina sp and Volvox sp). Green algae that were common to both dry and rainy season include Chlamydomonas sp, Chlorella sp, Lagerheimia sp, Tetraedron caudatum, T. minimum, T. regulare and Ankistrodesmus sp.

In the bottom waters in the rainy season, 20 species were recorded as opposed to 18 in the dry season. Green algae species that were common in both seasons include Chlorella sp, Lagerheimia $s p$, Closterium sp, Pediastrum simplex, Tetraedron spp, Scenedesmus quadricauda and Volvox sp.

\section{Division Cyanophyta}

The blue green algae exhibited a high dominance among the other taxa. A total of 8 species from 7 genera were present in both seasons in surface waters, of which 4 species were common in both seasons (Anabaena circinalis, Microcystis aureginosa, M. flos-aquae, and Synechococcus sp). Merismopedia sp, Nostoc sp, and Stigonema sp. occurred only in the dry season while Aphanocapsa sp, Arthrospira sp, Oscillatoria sp and Gleotrichia $s p$ occurred only in the rainy season. A similar trend was observed in the dry season, with both D1 and D2 having common species of blue green algae except for Aphanizomenon sp and Cylindrospermopsis $s p$ which were only found in D2 in the dry and rainy season respectively.

\section{Division Dinophyta}

Dinophyta had a total of 23 species from 17 genera, 13 families in the rainy season while in the dry season, there was an increase in species number in this group (36 species) in D1. For D2 there was no significant difference in the species composition for both seasons. Species common to both seasons include Amphisolenia spinolusa, Ceratium gravidum, C. hurundinella, C. inflatum, $C$. lineatum, Dinophysis caudate, Histoneis depressa, Amphidinium sp, Gymnodinium sp, Gyrodinium sp, Peridinium spp, Glenodium sp.

\section{Divisions Euglenophyta, Xanthophyta and Chrisophyta}

Four genera present in the division Euglenophyta were Cosmarium, Euglena, Phacus and Trachelomonas of the Class Euglenophyceae. Xanthophyta and Chrysophyta had the least occurrence. Three genera were present in the Xanthophyta namely; Tribonema, Vaucheria and Drapanaldia. These 3 genera were present in both surface and bottom water (except Vaucheria) in the rainy season. In the dry season only bottom water samples had species of Tribonema and Vaucheria; none of these species were present in surface water during the dry season.

For the Chrysophytes, one genus, Mallomonas with just one species, (Mallomonas sp) was present in bottom water samples during the dry season and none in surface waters; 4 genera (Chrysocapsa, Dinobryon (D. cranulatum and D. cylindricum), Mallomonas and Synura were recorded in bottom water samples during the rainy season.

The least represented algal group was Cryptophyta having only one genus (Cryptomonas) in the dry season in S4 while in the rainy season, a different genus, Rhodomonas was recorded in bottom samples.

\section{Ordinations}

Fig. 6 shows the ordination of species and measured parameters across sites and seasons. There is a clear seasonal (temporal) variation in the species abundant (Fig. 6 A). This difference is explained by the first component (99.9\%). While TDS is closely associated with the rainy season and its associated abundant species, there is no clear driver for species abundant in the dry season. However, Figure 6B shows that NH4-, TDS and turbidity determine the distinctness of Sites 2 and 5 in the Rainy season, compared to the other sites. These sites are mid-lake sites on the two lake faces studied. 

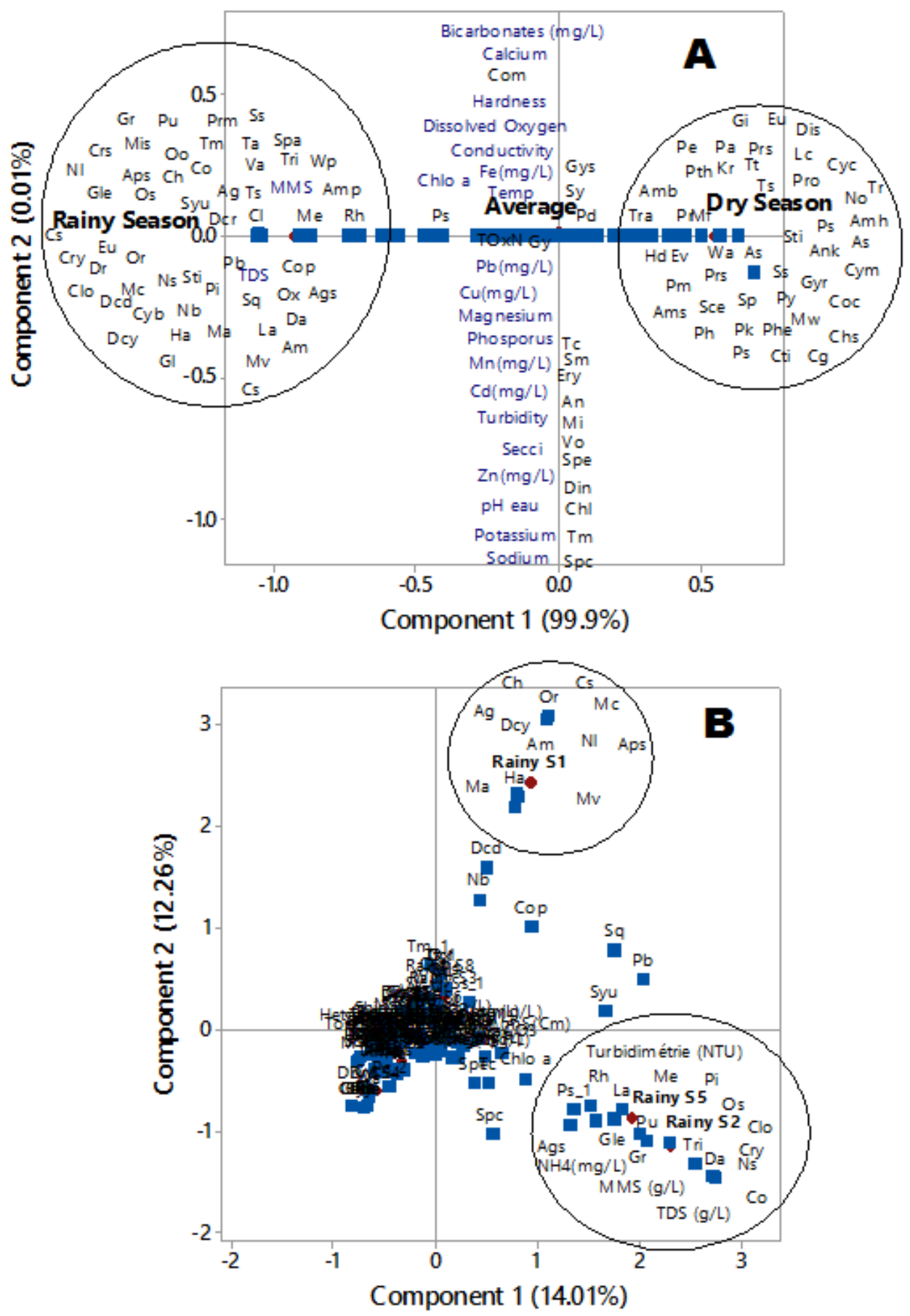

Fig. 6: Ordination of phytoplankton species and measured parameters across seasons (A) and seasons with sites (B).

[Abbreviations used: As = Acanthogonyaulax spirifera, Am = Achnanthidium minutissimum, Amp = Amphidinium poecilochroum, Amh = Amphisolenia sp, Amb = Amphisolenia bidentata, Ams = Amphisolenia spinulosa, $\mathrm{An}=$ Anabaena $\mathrm{sp}$, As = Ankistrodesmus sp, Ank = Ankyra sp, Aps = Aphanizomenon sp, Ag = Aulacoseira granulata, $\mathrm{Ags}=$ Aulacoseira $\mathrm{sp}, \mathrm{Cg}=$ Ceratium gravidum, $\mathrm{Cti}=$ Ceratium tripor, $\mathrm{Ch}=$ Ceratium hirundinella, $\mathrm{Cl}=$ Ceratium lineatum, $\mathrm{Clo}=$ Ceratium longipes, $\mathrm{Chs}=$ Chlamydomonas $\mathrm{sp}, \mathrm{Chl}=$ Chlorella $\mathrm{sp}, \mathrm{Cry}=$ Chrysocapsa $s p, \mathrm{Cs}=$ Closterium $s p, \mathrm{Cop}=$ Cocconeis pediculus, $\mathrm{Coc}=$ Cocconeis $s p, \mathrm{Co}=$ Coscinodiscus $s p$, Com $=$ Cosmarium $s p, \mathrm{Crs}=$ Cryptomonas $s p, \mathrm{Cym}=$ Cyclotella meneghiniana, $\mathrm{Cyc}=$ Cyclotella $s p, \mathrm{Cyb}=$ Cymbella $s p$, Dis = Dictyosphaerium $s p, \mathrm{Da}=$ Dinophysis acuta,, Din $=$ Dinophysis $s p$, Dcr $=$ Dinobryon cranulatum, Dcy $=$ Dinobryon cylindricum, Dcd $=$ Dinobryon divergens, $\mathrm{Dr}=$ Drapanaldia $s p$, Ery $=$ Erythropsis pavillardi, 
$\mathrm{Eu}=$ Euastrum $s p, \mathrm{Eu}=$ Euglena $s p, \mathrm{Ev}=$ Euglena viridis, $\mathrm{Gl}=$ Glenodinium $s p$, Gle = Gleotrichia $s p$, Gy = Gymnodinium sp, $\mathrm{Gi}=$ Gyrodinium instriatum, Gys = Gyrodinium sp, Gyr = Gyrodinium spirale, $\mathrm{Gr}=$ Gyrosigma sp, $\mathrm{Ha}=$ Haematococcus $s p, \mathrm{Hd}=$ Histoneis depressa, $\mathrm{Kr}=$ Katodinium rotundatum, $\mathrm{Lc}=$ Lagerhemia chodata, $\mathrm{La}=$ Lagheriemia $s p, \mathrm{Ma}=$ Malomonas $s p, \mathrm{Mv}=$ Melosira varians, $\mathrm{Mc}=$ Meridion circulare, $\mathrm{Me}=$ Merismopedia sp, $\mathrm{Mi}=$ Microcystics auraginosa, $\mathrm{Mf}=$ Microcystics flos-aqua, $\mathrm{Mw}=$ Microcystics wesenberger, Mis = Microspora $s p, \mathrm{Nb}=$ Navicula Bory, $\mathrm{Nl}=$ Nitzchia linearis, $\mathrm{Ns}=$ Nitzchia $s p$, No $=$ Nostoc $s p$, Os $=$ Oedegonium $s p$, Or $=$ Oscillatoria rubescens, Oo = Oocystics $s p$, Ox $=$ Oxytoxum $s p, \mathrm{~Pa}=$ Palmipes, $\mathrm{Ps}=$ Pandorina $\mathrm{sp}, \mathrm{Pd}=$ Pediastrum duplex, $\mathrm{Ps}=$ Pediastrum simplex, $\mathrm{Pe}=$ Peridinium $s p, \mathrm{Pu}=$ Peridinium umbonatum, $\mathrm{Ph}=$ Phacus $s p, \mathrm{Pm}=$ Phalacroma mitra, $\mathrm{Phe}=$ Pheopolykrikos hartmannii, $\mathrm{Pi}=$ Pinnularia $s p$, $\mathrm{Pk}=$ Polykrikos kofoidii, $\mathrm{Ps}=$ Polykrikos schwartzii, $\mathrm{Pb}=$ Prorocenteum belizeanum, $\mathrm{Pr}=$ Prorocentrium $s p$, Pro $=$ Prorocentrium rostratum, Prm $=$ Prorocentrum micans, Prs $=$ Protoceratium $s p$, Pth $=$ Protoperidinium therianum, $\mathrm{Prs}=$ Protoperidinium $s p, \mathrm{Py}=$ Pyrodinium $s p, \mathrm{Rh}=$ Rhizosolenia $s p, \mathrm{Sq}=$ Scenedesmus quadricauda, $\mathrm{Sce}=$ Scenedesmus $s p, \mathrm{Sm}=$ Schuetiella mitra, $\mathrm{Ss}=$ Schuettiella $s p, \mathrm{Ss}=$ Selenastrum $s p, \mathrm{Sp}=$ Spatulodinium pseudonoctiluca, $\mathrm{Spa}=$ Spatulodinium $s p, \mathrm{Spc}=$ Sphaerium corneum, $\mathrm{Spe}=$ Sphaerodinium $s p, \mathrm{Sti}=$ Stigonema $s p$, $\mathrm{Sti}=$ Stigeoclonium $s p, \mathrm{Sy}=$ Synechococcus $s p, \mathrm{Syu}=$ Synedra ulna, Tc $=$ Tetraedron caudatum, Tm $=$ Tetraedron mediocris, $\mathrm{Tm}=$ Tetraedron minimum, $\mathrm{Tr}=$ Tetraedron regulare, $\mathrm{Ts}=$ Tetraedron $s p, \mathrm{Ts}=$ Tetrastrum $s p$, $\mathrm{Tt}=$ Torodinium terodo, $\mathrm{Tra}=$ Trachelomonas $s p, \mathrm{Tri}=$ Tribonema $s p, \mathrm{Va}=$ Vaucheria $s p$, Vo $=$ Volvox $s p, \mathrm{Wa}=$ Warwonia sp, $\mathrm{Wp}=$ Warnowia polyphemus].

\section{Correlation of research parameters}

Table 5. Correlation analyses of studied parameters.

\begin{tabular}{|c|c|c|c|c|c|c|c|c|c|c|}
\hline & TOxN & TDS & MMS & Phosphorus & DO & Chlo a & Secci & pH eau & Abundance & Richness \\
\hline \multirow[t]{2}{*}{ TDS } & 0.391 & & & & & & & & & \\
\hline & 0.027 & & & & & & & & & \\
\hline \multirow[t]{2}{*}{ MMS } & 0.196 & 0.613 & & & & & & & & \\
\hline & 0.282 & 0.000 & & & & & & & & \\
\hline \multirow[t]{2}{*}{ Phosphorus } & 0.260 & -0.273 & 0.109 & & & & & & & \\
\hline & 0.150 & 0.130 & 0.553 & & & & & & & \\
\hline \multirow[t]{2}{*}{ DO } & -0.068 & 0.510 & 0.129 & -0.448 & & & & & & \\
\hline & 0.713 & 0.003 & 0.482 & 0.010 & & & & & & \\
\hline \multirow[t]{2}{*}{ Chlo a } & 0.557 & 0.429 & 0.151 & 0.063 & -0.032 & & & & & \\
\hline & 0.001 & 0.014 & 0.409 & 0.733 & 0.863 & & & & & \\
\hline \multirow[t]{2}{*}{ Secci } & 0.034 & 0.615 & 0.402 & -0.105 & 0.543 & 0.141 & & & & \\
\hline & 0.855 & 0.000 & 0.023 & 0.569 & 0.001 & 0.441 & & & & \\
\hline \multirow[t]{2}{*}{ pH eau } & -0.426 & 0.271 & 0.119 & -0.352 & 0.528 & -0.295 & 0.331 & & & \\
\hline & 0.015 & 0.133 & 0.516 & 0.048 & 0.002 & 0.101 & 0.064 & & & \\
\hline \multirow[t]{2}{*}{ Abundance } & 0.116 & -0.401 & -0.202 & 0.373 & -0.684 & 0.021 & -0.399 & -0.667 & & \\
\hline & 0.529 & 0.023 & 0.268 & 0.036 & 0.000 & 0.908 & 0.024 & 0.000 & & \\
\hline \multirow[t]{2}{*}{ Richness } & -0.014 & 0.389 & 0.349 & -0.374 & -0.013 & 0.192 & 0.350 & -0.152 & 0.080 & \\
\hline & 0.941 & 0.028 & 0.050 & 0.035 & 0.943 & 0.293 & 0.050 & 0.406 & 0.663 & \\
\hline \multirow[t]{2}{*}{ Fishers $\alpha$} & 0.004 & 0.422 & 0.382 & -0.384 & 0.083 & 0.194 & 0.403 & -0.102 & -0.049 & 0.980 \\
\hline & 0.984 & 0.016 & 0.031 & 0.030 & 0.652 & 0.287 & 0.022 & 0.577 & 0.789 & 0.000 \\
\hline
\end{tabular}

An analysis of the relationship between phytoplankton parameters revealed significant and positive correlations between some physicochemical parameters and nutrients (Table 5). At $\alpha=0.05$, Total Oxidizable Nitrogen was significantly positively correlated with chlorophyll $\mathrm{a}$, and indicator of phytoplankton biomass ( $\mathrm{r}=$
0.557) and TDS ( $\mathrm{r}=0.391)$. A strong negative correlation was found between ToxN and $\mathrm{pH}$ of water $(\mathrm{r}=-0.426)$. Phosphorus on the other hand had strong negative correlations with Dissolved Oxygen (DO) $(\mathrm{r}=-0,448)$, species richness and diversity $(\mathrm{r}=-0.384)$, but a positive correlation with species abundance $(r=0.373)$. Species abundance 
correlated negatively with DO concentrations, Sechi depth and $\mathrm{pH}$, but species diversity correlated positively with Sechi depth $(r=0.403)$.

\section{Discussion}

The aim of this study was to investigate the spatiotemporal dynamics of phytoplankton communities in the Lake Barombi Kotto, a volcanic crater lake subject to enormous anthropogenic activities. Phytoplankton dynamics, just as with other plants, are triggered by ecophysiological tolerance limits to biotic and abiotic conditions (Browning et al., 2014). Such conditions in the current study include physico-chemical characteristics, nutrients and heavy metals, whose dynamics in space and across seasons shape the resulting phytoplankton responses. We therefore discuss first dynamics of these abiotic conditions, and then show how they influenced the resultant phytoplankton communities in Lake Barombi Kotto, and the implications of such dynamics.

\section{Physico-chemical parameters}

Lake Barombi Kotto is a shallow tropical lake and so there was little vertical or horizontal stratification in temperature; even the mid lake sites (S2 and S5) which are expected to show variability in temperatures did not. This is because the larger water volumes at these deeper sites take longer to warm and cool down. The $\mathrm{pH}$ of Lake Barombi Kotto during this study period was neutral unlike most lakes of volcanic origin. This can be attributed to high inputs of freshwater from the inflowing stream at S7 (Tung Nsuria). The range of conductivity for this lake $(89.0-118 \mu \mathrm{S} / \mathrm{cm}$ for the rainy season) seems to be lower than that recorded by Corbet et al. (1973) in the same lake; however, conductivity increased with depth in both studies. This comparison with historical results (Corbet et al., 1973) show that in spite of the increase in anthropogenic activities over time, the lake has retained its fresh water status. Compared to the findings by Corbet et al. (1973), higher values were recorded for Secchi depth in the rainy season $(0.62 \mathrm{~m})$ than in the dry season $(0.38 \mathrm{~m})$. We found exceedingly high concentrations of TDS especially at Site 2, which partly account for this turbidity; in addition to this were the large phytoplankton blooms which occurred during the dry season. Dense masses or blooms are known to reduce water clarity and increase turbidity. In addition to the usual blooms, we found exceedingly large numbers of suspended organic pellets which were later identified to be composite colonies/associations of Microcystis species with Aulacoseira granulata. These occurred throughout the lake in both seasons and our record probably represents the first report of this association in freshwaters in the tropics. Compared with historical records for the same site, Secchi depth or transparency obtained in this study is way lower than that observed in Corbet et al. (1973) implying water clarity has reduced tremendously probably as a result of dense mats of phytoplankton in the lake which have given the lake a permanent green coloration, but also a result of increased siltation, as the surrounding forest which is under intense agricultural activities, releases deposits into the lake. In the current study, Secchi depth had an inverse relationship with phytoplankton abundance.

\section{Dissolved oxygen and nutrients}

Slightly higher values of dissolved oxygen in the rainy season can be attributed to lower rate of decomposition, low respiratory demand and the capacity of water to hold high oxygen concentration at low temperature (Manasrah et al., 2006). Thus there was a seasonal (temporal) and not a spatial variability in dissolved oxygen within the lake. The implications of this are discussed subsequently. Total Oxidizable nitrates and phosphorus varied with sites, depth and seasons. There was a vertical stratification in both ToxN and Dissolved inorganic Phosphorus concentration within the lake with higher concentrations in the bottom waters, away from the surface waters with higher transparency for primary production. Such nutrients become mixed within the water column during upwelling events.

Nutrient upwelling resulting from high winds and over-turns contribute to higher concentrations of 
phosphorus at certain periods of the year. Higher concentrations of phosphorus in the dry season could be attributed to reduction in water volume in the dry season as a result of reduced inflow, high solar radiation and evaporation. The highest concentration recorded in S7 in the dry season could be explained by the leaching of nutrients from nearby agricultural farmlands. Nutrient upwelling could in turn trigger phytoplankton blooms. According to Smith et al. (2006), the most important factor responsible for eutrophication of fresh water lakes is $\mathrm{P}$ and $\mathrm{N}$. In the present study, Total Oxidizable Nitrogen ranged between 0.84 $\mathrm{mg} / \mathrm{L}$ in $\mathrm{S} 7$ to $18.4 \mathrm{mg} / \mathrm{L}$ in $\mathrm{S} 2$ in the rainy season. High values were recorded during dry season which could be attributed to decomposition of organic matter at higher temperature and entry of nitrogen fertilizers from catchment areas. High values of phosphorus were recorded in dry season which can be related to decomposition of organic matter at high temperature, and decrease in water level leading to increase in concentration. Depending on the content of $\mathrm{N}$ and $\mathrm{P}$, these nutrients stimulate or limit algae development, especially in unpolluted, clear lakes. The strong negative correlation between phosphorus and species richness can be attributed to the fact that when phosphorus is high, only certain tolerant taxa can strive in such an environment.

\section{Heavy metals}

Significant variations in concentrations of Iron $(\mathrm{Fe})$, zinc $(\mathrm{Zn})$ and copper $(\mathrm{Cu})$ across sites and seasons suggests that the origins are not natural. Higher values in these metals were recorded in the sites along the agricultural farmlands, suggesting anthropogenic origins. As it is well-known, iron is an essential trace element for biological requirements of phytoplankton and aquatic plants (Browning et al., 2014). It can be involved in chlorophyll pigment biosynthesis, in many components of photosynthesis (PS I and PS II) and electron transport systems, as well as in nitrate assimilation as an enzyme cofactor (nitrate reductase and nitrite reductase). Therefore, iron concentration promotes growth and physiological metabolisms of phytoplankton. Iron influences algal productivity and species composition in freshwater lakes. It is reported that when iron concentration ranges from 0.1 to $1.0 \mathrm{mg} \mathrm{l}^{-1}$, algal community in lakes shifts from green algae to cyanobacteria (Wei and Guihua, 2011). This is in line with studies by Pollingher et al. (1995) who also found that iron addition affects species composition of phytoplankton in Lake Kinneret, and markedly promoted the growth of green algae and bacteria.

\section{Spatial and temporal dynamics in phytoplankton communities in relation to abiotic conditions}

Phytoplankton occurrence in lakes is a natural phenomenon; however, what drives their dynamics clearly relates to their ecophysiological tolerances to changes in abiotic conditions (Browning et al., 2014). Changes in abiotic conditions could be natural or a result of anthropogenic activities, either directly or through activities carried out in the river basin as a whole. These influences affecting lakes result in modifications to the structure and composition of the phytoplankton, which may take the form of changes in the taxa of which the algal associations are composed, in the abundance of each taxa, the richness and diversity of the associations, and other community parameters. In this section we highlight the following findings from our study of Lake Barombi Kotto:

1. There was vertical stratification in abundance of Bacillariophyta, Chlorophyta, Cyanophyta and Dinophyta.

2. There were changes in community structure with seasons in the Cyanophyta, but the indicators of eutrophication were ubiquitous irrespective of the season.

3. Concentrations of ToxN and Phosphates drive phytoplankton biomass and abundance, but only to an extent.

\section{Vertical stratification in abundance of some divisions}

The overall abundances of phytoplankton were 
relatively high compared to other records. Irrespective of season, there was a top-bottom stratification in the abundance of the Bacillariophyta, Chlorophyta, Cyanophyta and Dinophyta. The mechanisms for settling in each division and constituent species are not clear. Typical drivers of stratification in biota include stratification in the physico-chemical parameters including temperature, $\mathrm{pH}$, and nutrients (Goldman et al. 1996; Mellard et al. 2011). In the current study, there was no thermal stratification, but both phosphate and nitrate concentrations were significantly higher in the bottom of the lake and could drive blooms of particular high biomass phytoplankton. While high phytoplankton abundance occurred in the bottom waters with low DO concentrations, diversity seem to increase in the surface waters where adequate lighting drive multiple species' survival.

\section{Seasonal (temporal) shifts in the composition of major divisions especially the Cyanophyta}

There were species shifts in the divisions Cyanophyta, Dinophyta, Xanthophyta, Crysophyta and Cryptophyta as the seasons changed from rainy to dry season. These seasonal shifts correspond to seasonal changes in physico-chemical parameters of the lake, but also indicate the diverse nature of phytoplankton in general. This is in line with the findings of Adon et al. (2011) in a shallow fresh water reservoir in Côte d'Ivoire. Barone and Naselli-Flores (2003) reported that species have different strategies in terms of size, shape, cell content to cope with the need for keeping afloat, sink and or rotate and therefore may take advantage of different perhaps overlapping niches within the photic layer. Our studies revealed the dominance of species of Cyanophyta, Dinophyta and Chloropyta. The most abundant species in terms of population density were Mycrocystis aureginosa, M. flosaquae, Amphisolenia bidentata. The Cyanophyta, more specifically species of Microcystis, are toxic to humans; the presence of groups of toxic algae especially the Microcystis species in a water body under intensive human use represent a considerable socioecological risk (de Figueiredo, 2004;
Wu et al., 2017). The presence of Merismopedia and Oscillatoria spp. were also indicative of pollution. Blue-green algae remained dominant in the lake during both seasons in the present investigation because they are able to grow under the condition of weak light, low temperature and low nutrient levels compared to other algae. Indeed, across seasons, the Euglenophycean Index was markedly less than 1 , showing that year-round the lake was eutrophic - due to the predominance of Chlorophytes and Cyanophytes.

Cyanophyceae are more efficient in utilizing $\mathrm{CO}_{2}$ at high $\mathrm{pH}$ level and low light availability and thus, their abundance indicates the eutrophic nature of water body. Blue-green algal (Cyanophyceae) abundance was found to be the major portion in the phytoplankton community during dry season. While most phytoplankton groups are limited by nutrient concentrations especially nitrates, the Cyanophyta contains nitrogen fixing species that would thrive in nitrates-poor waters (Kolzau et al., 2014). Dinoflagellates on the other hand were so diverse and abundant in almost all the sites and seasons, especially at D2. This can be explained by the fact that this group is advanced and most members possess flagellae which enable them to migrate to portions of the water column with prevailing nutrients and other abiotic conditions. Distinct algal communities at the different depths is explained by the fact that this lake is stratified in terms of light and nutrients.

Euglenoid algae form a relatively large and diverse group but few species are truly planktonic. They are facultative heterotrophs and generally abundant in waters rich in organic matter. Euglenophyceae in the present study formed one of the least represented group of phytoplankton (4 species), which were represented by only 3 genera, Euglena, Trachelomonas and Phacus. With respect to the phytoplankton community succession, Euglenophyceae in the present study started emerging in rainy season and showed their higher proportion in the phytoplankton community in the dry season. Increasing temperature and accumulation of organic loads from surface run-off, autothonous 
and allocthonus organic load, sewage and clear sunshine may be the reasons for the dominance of Euglenophyceae in the dry season.

Irrespective of the Division, there were more consistent trends in species abundance, richness and diversity in the dry season compared to rainy season which suggests that the rainy season represents a disturbed ecology. During the rains, high water inflows from the inlet result in mixing of the waters, distorting any prior stratification. This situation continues for eight months of the year. Therefore the fact that the lake remains eutrophic during this period suggests that the incoming waters and runoff from surroundings bring in large loads of nutrients. A complete nutrient budget for the lake is the subject of a different article.

\section{Concentrations of ToxN and Phosphates drive phytoplankton biomass and abundance, but only to an extent}

A number of workers have reported many algal species as indicators of water quality (Onyema, 2013; Fonge et al., 2015; Zargar and Ghosh, 2006). Zargar and Ghosh (2006) in a study on Kadra reservoir of Karnataka lists several algal forms belonging to Chlorophyceae, Cyanophyceae, Euglenophyceae and Bacillariophyceae as indicators of water pollution. However, indicators only respond to ambient abiotic conditions. In the current study, correlation analyses showed that phytoplankton biomass and dissolved solutes depend on concentrations of ToxN, increasing as the latter increased. However, species richness and diversity seemed to be limited among others, by phosphate concentrations, with which they have a negative correlation; there are some species that depend on phosphates for rapid growth - hence high abundance, and quick cycles of blooms that rapidly decrease DO, species richness and diversity. Phytoplankton abundance correlated negatively with DO concentrations, Secchi depth and water $\mathrm{pH}$. However, results of ordination show an inconclusive picture, suggesting that parameters other than those studied also contribute to the observed dynamics.
The Lake Barombi Kotto is subjected to pollution due to surface run-offs from Island and mainland settlements, fertilizers from agricultural lands and domestic sewage. Fertilizers used in this area are typically composites of nitrates, potassium and phosphates. Due to the surrounding topography, all runoff eventually ends in the lake, bringing with it these nutrients, and possibly sewage from poorly constructed latrines. Progressive enrichment of water with nutrients leads to mass production of algae; blooms of algae rapidly deplete DO concentrations; algae die out releasing nutrients, and a further cycle of bloom occurs. The rainfall is insufficient for adequate flushing, and thus high nutrient retention times ensure that the lake is in a permanent eutrophic state. This has severe socioecological implications, since the population uses the lake for fishing, boating, swim races, bathing and other domestic purposes.

\section{Conflict of interest statement}

Authors declare that they have no conflict of interest.

\section{Acknowledgement}

We thank the population of Barombi Kotto headed by the Chief, HRH Chief Pyndian Moni Bakoh for granting us access to the Lake for this research. Chief Bakoh also provided the research boat. Mr Bakoh Ndinkoka, and Ekomo Solomon are thanked for navigating the research boat and assisting with sample collection.

\section{Author contributions}

This research was conceived by Beatrice Fonge, Awo Miranda and Pascal Tabot. All authors participated in the field research. Awo Miranda and Nsoh Goodenough conducted/coordinated the laboratory analyses for all parameters; Fonge Beatrice conducted the Phytoplankton identification; Pascal Tabot did the statistical analyses; All authors contributed in the writing of the manuscript. 


\section{References}

Adon, M.P., Ouattara, A., Gourene, G., 2011. Seasonal ariation in the diversity and abundance of phytoplankton in a small African tropical reservoir. Afr. J. Microbiol. Res. 5(18), 26162626.

American Public Health Association (APHA), 2005. Standard methods for the examination of water \& wastewater. $21^{\text {st }}$ Edn, Eaton, A.D., Clesceri, L.S., Rice, E.W., Greenberg, A.E., Franson, M.A.H. APHA, Washington.

Anyinkeng N., Mih, A.M., Tening, A.S., Awah, C.C., 2016. Phytoplanktion diversity and abundance in water bodies as affected by anthropogenic activities within Buea municipality, Cameroon. J. Ecol. Natural Environ. 8(7) 99-114.

Barone, R., Naselli-Flores, L., 2003. Distribution and Seasonal dynamics of Cryptomonads in Sicilian water bodies. Hydrobiologia. 502, 325329.

Bellinger, G.E., Siegee, D.C., 2010. Fresh Water Algae: Identification and use as Bio-Indicators. $1^{\text {st }}$ edition. John Wiley and Sons Ltd. 271 p.

Browning, T.J., Bouman, H.A., Moore, C.M., Schlosser, C., Tarran, G.A., Woodward, E.M.S., Henderson, G.M., 2014. Nutrient regimes control phytoplankton ecophysiology in the South Atlantic. Biogeosciences. 11, 463-479.

Corbet, S.A., Green, J., Griffith, J. Betney, E. 1973. Ecological studies on crater lakes in West Cameroon, Lakes Kotto and Mboandong. J. Zool. 170, 309-324.

Cottenie, A. Verloo, M. Kieken, E. Velghe, G. Camerlynk, R. 1982. Chemical analysis of plant and soil Ghent , 40 pp. Belgium.

de Figueiredo, D.R., Azeiteiro, U.M., Esteves, S.M., Gonçalves, F.J., Pereira M.J., 2004. Microcystin-producing blooms-a serious global public health issue. Ecotoxicol. Environ. Safe. 59, 151-163.

Fisher, R. A., Corbet, A. S., Williams, C. B., 1943. The relation between the number of species and the number of individuals in a random sample of an animal population. J. Anim. Ecol. 12, 4258 .
Fonge, B.A., Tabot, P.T., Chop, A.M., Mumbang, C., 2015. Phytoplankton community structure and physico-chemical characteristics of streams flowing through an agro- plantation complex in Tiko, Cameroon. J. Ecol. Natural Environ. 7(5), 170-179.

Ganai, A.H., Parveen, S., 2014. Effect of physicochemical conditions on the structure and composition of the phytoplankton community in Wular Lake at Lankrishipora, Kashmir. Int. J. Biodiv. Conserv. 6(1), 71-84.

Goldman, C.R., Elser, J.J, Richards, R.C., Reuters, J.E., Priscu, J.C. and Levin, A.L., 1996. Thermal stratification, nutrient dynamics, and phytoplankton productivity during the onset of spring phytoplankton growth in Lake Baikal, Russia. Hydrobiologia 331(1-3): 9-24.

Kolzau, S., Wiedner, C., Rucker, J., Kohler, J., Kohler, A., and Dolman, A.M., 2014. Seasonal Patterns of Nitrogen and Phosphorus Limitation in Four German Lakes and the Predictability of Limitation Status from Ambient Nutrient Concentrations. PLoS One. 9(4), e96065.

Magurran, A. E., 1981. Biological diversity and woodland management. Unpublished D.Phil.thesis, New University of Ulster.

Manasrah, R., Raheed, M., Badran, M.I., 2006. Relationships between water temperature, nutrients and dissolved oxygen in the northern Gulf of Aqaba, Red Sea. Oceanologia. 48(2), 237-253.

Mellard, J.P., Yoshiyama, K., Litchman, E., Klausmeier, C.A., 2011. The vertical distribution of phytoplankton in stratified water columns. J. Theor. Biol. 269, 16-30.

Moelants, T., 2010. Tilapia kottae. The IUCN Red List of Threatened Species 2010: e.T21898A9337471. http://dx.doi.org/10.2305/ IUCN.UK.2010-3.RLTS.T21898A9337471.en

Murphy, J. Riley, J.P., 1962. A modified single solution method for the determination of phosphate in natural waters. Anal. Chim. Acta. 27, 31-36.

Neale, P.J., Sobrino, C., Segovia, M., Mercado, J.M., Leon, P., Cortés, M.D., Tuite, P., Picazo, A., Salles, S., Cabrerizo, M.J., Prasil, O., Montecino, V., Reul, A., Fuentes-Lema, A., 
2014. Effect of $\mathrm{CO}_{2}$, nutrients and light on coastal plankton.; Abiotic conditions and biological responses. Aquat. Biol. 22, 25-41.

Nguetsop, V.F., Fonko, U.T., Assah, V.M.D., Nangtson, M.N., Pinta, J.Y., 2007. Relationship between algae and physicochemical characteristics of water in wetlands and water bodies, Cameroon. J. Exp. Biol. 3, 70-79.

Nkengazong, L., Njioku, F., Teukeng, F., Enyong, P., Wanji, S., 2009. Reassessment of the endemicity level of urinary schistosomiasis in the Kotto-Barombi focus (South West Cameroon) and impact of mass drug administration (MDA) on the parasitic indices. J. Cell Anim. Biol. 3(9), 159-164.

Onyema, I.C., 2013. Phytoplankton Bio-indicators of Water Quality Situations in the Iyagbe Lagoon, South-Western Nigeria. Acta SATECH 4(2), 93-107.

Paerl, H.W., Futton, R.S., Moisander, P.H., Dyble, J., 2001. Harmful freshwater algal blooms with an emphasis on Cynobacteria Scient. World. 1, 76-113.

Pollingher, U., Kaplan, B., Berman, T., 1995. The impact of iron and chelators on Lake Kinneret phytoplankton. J. Plankton Res. 17, 1977-1992.

Poole, R. W., 1974. An Introduction to Quantitative Ecology. McGraw-Hill Kogakusha, Tokio.

Reynolds, C.S., 2006. Ecology of Phytoplankton. Cambridge University Press.

Salmaso, N., Naselli-Flores, L., Padisák, J., 2012. Impairing the largest and most productive forest on our planet: how do human activities impact phytoplankton? Hydrobiologia. 698(1), 375384.

Sanseverino, I., Conduto, D., Pozzoli, L., Dobricic S., Teresa Lettieri, T., 2016. Algal bloom and its economic impact; EUR 27905 EN; doi: $10.2788 / 660478$

Smith, V.H., Joye, S.B., Howarth, R.W., 2006. Eutrophication of freshwater and marine ecosystems. Limnol. Oceanogr. 51, 351-355.

Tabi, E.B., Oben, P.M., Oben, B.O., 2015. Diversity and dynamics of potentially toxic Cyanobacteria and their public health significance in Lake Koto Barombi, Cameroon. Trop. Freshwater Biol. 25. http://dx.doi.org/ 10.4314/tfb.v24i1.7

Tabot, P.T., Che, C.A., Fonge, B.A., 2016. Water quality of Lake Barombi Mbo, a volcanic crater lake and associated point sources. Int. J. Curr. Microbiol. Appl. Sci. 5(7), 518-536.

Talling, J.F., Driver, D., 1961. Some problems in estimation of chlorophyll a in phytoplankton, In: Proc. Conf. Primary Production Measurement in Freshwater (Ed.: Doty, M.S.). University of Hawaii. US Atomic Agency Publication TID7633. pp.142-146.

Tening, A.S., Asongwe, G.A., Chuyong, G.B., Fonge, B.A., Mvondo-Ze, A.D., 2014. Heavy metals status in the Rio Del Rey Mangroves of Cameroon. Int. J. Curr. Microbiol. Appl. Sci. 3(12), 701-717.

Van Reeuwijk, L.P., 2002. Procedures for Soil Analysis, International Soil Reference and Information Centre (ISRIC) Technical Paper, no. 9, ISRIC. 19 p.

Wei, X., Guihua, L., 2011. Iron biogeochemistry and its environmental impacts in freshwater lakes. Fresenius Environ. Bull. 20(6), 13391345.

Wu, H., Wei, G., Tan, Xiao, Li, L., Li, M., 2017. Species-dependent variation in sensitivity of Microcystis species to copper sulfate: implication in algal toxicity of copper and controls of blooms. Scient. Rep. 7, No.: 40393. doi:10.1038/srep40393

Zargar, S., Ghosh, T.K., 2006. Influence of cooling water discharges from Kaiga nuclear power plant on selected indices applied to plankton population of Kadra reservoir. J. Environ. Biol. 27, 91-198.

\section{How to cite this article:}

Egbe, A. M., Tabot, P. T., Goodenough, N., Ambo, F. B., 2018. Spatiotemporal variation of phytoplankton community structure in the Crater Lake Barombi Kotto, Cameroon. Int. J. Curr. Res. Biosci. Plant Biol. 5(2), 36-55. doi: https://doi.org/10.20546/ijcrbp.2018.502.005 